\title{
Analysis of the End To End Operation in Its Recruitment for Lateral Hires
}

\author{
Arthi Priyadarsini. P, B. Shanmuga Priya
}

\begin{abstract}
In this study, to analyze the end to end recruitment both primary and secondary data were used. The Primary data is collected from the current employees, who perform the end to end IT recruitment. The secondary data is used on the verification side of the primary data, on the other hand primary data is highly used which gives the result. The sample size is 30 Current employees. The primary data is analyzed with the percentage analysis. The goal set of this study is "Once the required number and kind of human resources are determined, the management has to find the places where the required human resources are/will be available and also find the means of attracting them towards the organization before selecting suitable candidates for jobs ".
\end{abstract}

Keywords: Experience, Recruitment, Skills, Technology.

\section{INTRODUCTION}

$T_{\text {he success and Professionalism of an organization }}$ largely depends on the intensity of its recruitment. Selecting the right and able candidates can positively develop an impact in the growth of the organization which in turn helps in achieving the long-term goals of the organization in a comparatively shorter period of time. Therefore, recruitment must be given high concentration to avoid instability in the workplace. Preferring the right candidates for the right role is the key to the successful recruitment.

A recruitment process has to be organized in order to hire the candidates that can fulfill the expected roles and responsibilities. A new hire should always be made aware of the skills that are priorities for the role to be assigned. However, it is not always possible to select only the right candidates but by keeping the procedures and steps organized and appropriate one can reduce the possibility of risks and thereby increasing the potential. That's why it is very essential to devote the required time in selecting candidates rather than doing it in a rush. With such well-planned recruitment team, every department of the organization can flourish. To select the right candidates, the candidates with equivalent and expected skills must be made to apply for the

Revised Manuscript Received on December 16, 2019

* Correspondence Author

Arthi Priyadarsini.P*, Department of Business Administration, Kalasalingam Academy of Research and Education, Krishnankoil, Virudhunagar- 626126, Tamilnadu, India. Email: priyadarsiniarthi@gmail.com

B.Shanmuga Priya, Department of Business Administration, Kalasalingam Academy of Research and Education, Krishnankoil, Virudhunagar-626126, Tamilnadu, India. Email: b.shanmugapriya@klu.ac.in process. Therefore, efforts are needed to make the right candidates

apply. This can be achieved by attracting them through various modes of job portals, online forms, advertisements etc. All these are essential to find out the right candidate for the right role.

\section{STATEMENT OF THE PROBLEM}

Nowadays through various recruitment sources, mass number of candidates can apply for limited vacancies because of which selecting the appropriate candidate becomes difficult. To overcome this, we must be sure of the recruitment policy and the underlying factors that influence them. But the difficulty is most of these corresponding factors and the data associated with them are confidential. Therefore we must get access to the open data, and deliver it to the recruiter after centralizing them which is the process in end to end recruitment.

\section{OBJECTIVES OF THE STUDY}

1. To find out the new technologies adopted by the firm in the recruitment process and learn how to handle different job portals.

2. To study the importance of the factors that influences the recruitment policy. And to understand the challenges faced by the HR in acquiring best talent.

\section{METHODS / STATISTICAL ANALYSIS}

In this study both primary and secondary data were used. The Primary data is collected from the current employees, who perform the end to end IT recruitment. The secondary data is used on the verification side of the primary data, on the other hand primary data is highly used which gives the result. The sample size is 30 Current employees. The primary data are analysed with the percentage analysis. The goal set of this study is "Once the required number and kind of human resources are determined, the management has to find the places where the required human resources are/will be available and also find the means of attracting them towards the organization before selecting suitable candidates for jobs".

\section{METHODOLOGY}

Survey method is being used in this study and it is empirical. For analysis, data from

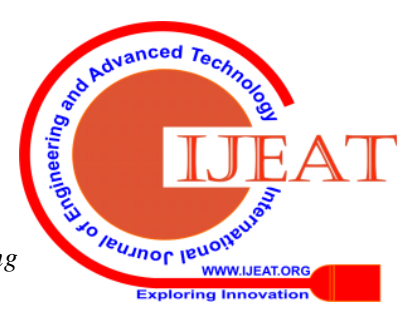


primary and secondary source are collected. Both primary and secondary data is used in the analysis also. From the recruiter's data is collected in the form of questionnaires, interview schedules, screening tests etc.

The questions play a major role in drawing us close to the finding of results because they give us the experiences of the respondents Even if the respondents have so much regarding information related to the study but the questions were not appropriate then the purpose of the study will not be served and it will be left meaningless. Therefore, the questions prepared for the research study serves as the central theme for the research and also contribute more to the success of the research. This study is an empirical study based on a survey method. In this study, both primary and secondary data were used This research is a systematic one consisting of an existing problem, collected facts and figures, analyzed facts and proposed conclusions in the form of recommendations.

\section{A. Forecasting of manpower requirement}

The Manpower requirement is the core component of recruitment. The forecasting of the manpower is based on the following factors given below and is in the tabulated form. $20 \%$ of the respondents is for total cost of the project. $40 \%$ is for past experience. $30 \%$ is for different phases of the project. Remaining $10 \%$ of the respondents agree to all the three factors namely total cost of the project, past experience and different phases of the project as shown in Table I

Table I: Factors influencing manpower

\begin{tabular}{|c|c|c|c|}
\hline SI.No. & Opinion & $\begin{array}{c}\text { No. of } \\
\text { respondents }\end{array}$ & $\begin{array}{c}\text { Percentage } \\
(\%)\end{array}$ \\
\hline 1. & $\begin{array}{c}\text { Total cost of the } \\
\text { project }\end{array}$ & 6 & 20 \\
\hline 2. & Past experience & 12 & 40 \\
\hline 3. & $\begin{array}{c}\text { Different phases of } \\
\text { the project }\end{array}$ & 9 & 30 \\
\hline 4. & All the above & 3 & 10 \\
\hline
\end{tabular}

\section{B. Reason for the preference of Past experience:}

Usually the company fixes the Demand based on the past experience and it is the best way to forecast the demand for future prediction.

\section{Recruitment policy}

To find whether the recruiters are satisfied with the policy which is followed by the organization and to measure the satisfaction of the recruiters.

Table II: Satisfaction measurement

\begin{tabular}{|c|c|c|c|}
\hline Sl. No. & Opinion & $\begin{array}{c}\text { No. of } \\
\text { respondents }\end{array}$ & $\begin{array}{c}\text { Percentage } \\
\%\end{array}$ \\
\hline 1. & Yes & 2 & 90 \\
\hline 2. & No & 3 & 10 \\
\hline
\end{tabular}

\section{Reason for the Satisfaction of the current recruitment policy.}

$90 \%$ of the employees are satisfied with the current policy because their talents are identified and the Monetary and Non-monetary benefits are given at right time to the right person.

\section{E. Sources of Recruitment}

To find the usage of the sources in recruitment and to measure whether the recruiters use both.

Table III: Usage of sources

\begin{tabular}{|c|c|c|c|}
\hline S No. & Opinion & $\begin{array}{c}\text { No. of } \\
\text { responders }\end{array}$ & $\begin{array}{c}\text { Percentage } \\
\%\end{array}$ \\
\hline 1. & Internal & 6 & 20 \\
\hline 2. & External & 18 & 60 \\
\hline 3. & Both & 6 & 20 \\
\hline
\end{tabular}

\section{F. Reason for Preferring External Sources}

External sources play a major role in end to end IT recruitment, because the profile is new to the market and easy to find duplicate and Cost effectiveness could be the major reason for using this method.

\section{G. External Sources}

There is Number of external sources, for measuring few has been considered. While the external sources are highly preferred by the recruiters, to go in detail; their preferred Opinion are also measured and the usage of the popular job sites are taken into account.

Table IV: External sources

\begin{tabular}{|c|c|c|c|}
\hline S No. & Opinion & $\begin{array}{c}\text { No. of } \\
\text { respondent }\end{array}$ & $\begin{array}{c}\text { Percentage } \\
\%\end{array}$ \\
\hline 1. & $\begin{array}{c}\text { Employee exchange } \\
\text { Consultant }\end{array}$ & 6 & 20 \\
\hline 2. & $\begin{array}{c}\text { Private employee } \\
\text { Agencies }\end{array}$ & 6 & 20 \\
\hline 3. & Advertisement & 3 & 10 \\
\hline 4. & Internet & 12 & 40 \\
\hline 5. & Any other & 3 & 10 \\
\hline
\end{tabular}

\section{H. The reason for preferring internet}

Internet also includes the Job Portal likes Naukri, Monster are some of the Paid portals and LinkedIn is the Non-paid portal where the recruiters can have a conversation with the candidates before the interview process and this could be one the major reason for choosing Internet as their preferred sourcing sites.

\section{Application / Recommendation}

This study suggest to improve external source for sourcing the qualified profiles through online portals. To avoid

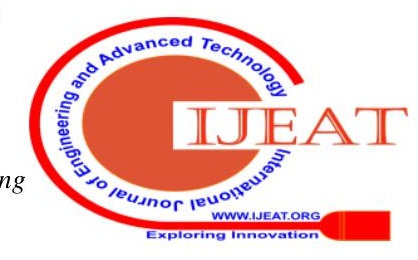


duplication, the data which should be maintained in central part. It also recommends Applicant Tracking System (ATS) for keeping a track of candidates so that it is more efficient to manage. "The firm should bring in practice the concept of video resume and train the employees regarding the same who are not aware of it", this will decrease the duplication.

\section{FINDINGS}

The process of recruitment is very complicated which starts from Manpower planning and ends with exit interviews, only when the person leaves the organization $70 \%$ of the employees are engaged in external recruitment and the rest are engaged in internal recruitment. Naukri.com, LinkedIn and Monster are some of the most common job portals used for sourcing purpose by the recruitment team. As per the Principal Component Analysis of the prime competencies considered while recruiting a candidate, four competencies i.e. Experience, Technical knowledge, Innovative ability and Communication skills of the candidates have been extracted.

\section{RESULT OF THE STUDY}

The data of the study is formulated based on the forecasting of the Man power requirement. Whether the current recruitment policy helps the recruiter to perform the job easily and effectively. The study correlates the internal and external sources of recruitment and the study ends with the solution for the preference of the recruiter in external sources. Technology also plays a major role in the form availability of sources such as various jobs portals and registration forums. And one of the challenges in recruitment is the identification of the appropriate external source.

\section{CONCLUSION}

Keyword search on job portal is the most reliable as compared to the Boolean search as per the employees of the firm. The employees of the firm get maximum job responses by calling through job portals and mass mailing or bulk SMS and very few from job posting and direct approaches of candidates.

\section{REFERENCES}

1. Adeyemi, O. S. Dumade, E. O, \& Fadare, O. M.. The influence of recruitment and selection on organizational performance the influence of recruitment and selection on organizational performance IJAAR ,2015.

2. 2.Dickie C \& Dwyer J, A 2009 perspective of HR practices, Journal of Management Development, Vol. 30, No. 4,2011. pp. 329-343.

3. Dr.SnehaMankikar (2014). "A Critical Study on Recruitment and Selection with reference to HR Consulting Firms. Volume: 3 | Issue: 3 | March 2014, ISSN - 2250-1991. • GamageAruna S (2014). "Recruitment and Selection Practices in Manufacturing SMEs in Japan: An analysis of the link with business performance". Journal of Management and Finance (RJMF), Volume 1 Number 1 - January 2014, ISSN 2235-9222.

4. Gilbert, C., De Winnie, S., \& Sels, L. (2011). The influence of line managers and HR department on employees ${ }^{\text {ee }}$ affective commitment. The International Journal of Human Resource Management[online], 22, 1618- 1637.10.1080/09585192.2011.5656462.How to Measure Human Resource Management, Jac Fitz-Enz [22] HR from the Heart: Inspiring Stories and Strategies for Building the People Side of Great Business, Libby Sartain,2003

5. Malhotra MN. A Study of the Recruitment and Selection process: SMC Global. Zenith International Journal of Multidisciplinary Research, 2014.
6. Human Relations: The Art and Science of Building Effective Relationships, Vivian McCann Hamilton, 2007.

7. Ntiamoah, E.B. 2014. „An investigation into recruitment and selection practices and organizational performance. "In International Journal of Economics, Commerce, and Management. 2 (11): 1-11. ISSN 2348-0386.

8. NtiamoahBrako Evans (2014). “An Empirical Analysis of Recruitment and Selection Practices in the Public Sector", International Journal of Management Sciences and Business Research, 2014, Vol-3, Issue 12, ISSN (2226-8235)

\section{AUTHORS PROFILE}

Arthi Priyadarsini.P is currently a full time Research Scholar in Kalasalingam Academy of Research and Education, Krishnankoil, Virudhunagar-626126, Tamilnadu, India. She received M.B.A., degree from Kalasalingam Academy of Research and Education,Krishnankoil-Tamilnadu, India

Dr.B.Shanmuga Priya is actively working as a assistant professor in the department of management studies at Kalasalingam Academy of Research and Education. 